\title{
Restructuring service at a mastology outpatient clinic during the COVID-19 pandemic
}

\author{
Reorganização do atendimento em ambulatório de mastologia durante a pandemia de COVID-19 \\ Reorganización de la asistencia en mastología ambulatoria durante la pandemia de la COVID-19
}

Cristina Poliana Rolim Saraiva dos Santos ${ }^{1,1}$
ORCID: 0000-0001-9643-0264

Ana Fátima Carvalho Fernandes' ORCID: 0000-0001-5110-6364

Denise Montenegro da Silva' ORCID: 0000-0001-6969-4133

Régia Christina Moura Barbosa Castro' ORCID: 0000-0002-0673-9442

'Universidade Federal do Ceará. Fortaleza, Ceará, Brazil. "Maternidade Escola Assis Chateaubriand. Fortaleza, Ceará, Brazil

How to cite this article: Santos CPRS, Fernandes AFC, Silva DM, Castro RCMB. Restructuring service at a mastology outpatient clinic during the COVID-19 pandemic. Rev Bras Enferm. 2021;74(Suppl 1):e20200571. doi: http://dx.doi.org/10.1590/0034-7167-2020-0571

Corresponding author:

Cristina Poliana Rolim Saraiva dos Santos E-mail: polianarolim@yahoo.com

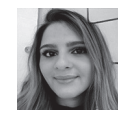

EDITOR IN CHIEF: Dulce Barbosa ASSOCIATE EDITOR: Alexandre Balsanelli

Submission: $05-28-2020$

Approval: 08-09-2020

\section{ABSTRACT}

Objective: to report the experience of a health team in restructuring service at a mastology outpatient clinic. Methods: an experience report in a public university service mastology outpatient in Ceará between March and April 2020. Service in this outpatient clinic is exclusively for women and who have breast changes for surgical treatments ranging from nodulectomies to mastectomies with oncoplastic. Results: increased COVID-19 cases brought the need to restructure healthcare services. The following steps were followed: identification of scheduled patients, reading of clinical developments in electronic medical records, individual assessment to define whether or not appointment would remain, telephone contact to inform about unscheduling. Among the 555 consultations scheduled for March and April 2020, 316 (56.9\%) were maintained. Final considerations: restructuring consultations at a mastology outpatient clinic optimized the waiting time for consultations and avoided crowds at service, providing patient safety.

Descriptors: Coronavirus Infections; Breast Neoplasms; Patient Care Team; Ambulatory Care; Women's Health.

\section{RESUMO}

Objetivo: relatar a experiência da equipe de saúde na reorganização dos atendimentos em ambulatório de mastologia. Métodos: relato de experiência em ambulatório de mastologia de serviço público universitário no Ceará entre março e abril de 2020. O serviço atende, exclusivamente, mulheres e que estão com alterações mamárias, para tratamentos cirúrgicos variando desde nodulectomias a mastectomias com oncoplástica. Resultados: o aumento dos casos de COVID-19 trouxe necessidade de reorganizar atendimentos em serviços de saúde. Seguiram-se as seguintes etapas: identificação das pacientes agendadas, leitura das evoluções clínicas nos prontuários eletrônicos, avaliação individual para definição da permanência ou não da consulta, contato telefônico para informar sobre a desmarcação. Dentre as 555 consultas agendadas para março e abril de 2020, 316 (56,9\%) foram mantidas. Considerações finais: a reorganização dos atendimentos no ambulatório de mastologia otimizou o tempo de espera das consultas e evitou aglomerações no serviço, propiciando segurança às pacientes atendidas.

Descritores: Infecções por Coronavírus; Neoplasias de Mama; Equipe de Assistência ao Paciente; Assistência Ambulatorial; Saúde da Mulher.

\section{RESUMEN}

Objetivo: reportar la experiencia del equipo de salud en la reorganización de la atención en una consulta externa de mastología. Métodos: relato de experiencia en un servicio de mastología ambulatoria de un servicio público universitario en Ceará entre marzo y abril de 2020. El servicio atiende exclusivamente a mujeres y aquellas con alteraciones mamarias, para tratamientos quirúrgicos que van desde nodulectomías hasta mastectomías con oncoplásticos. Resultados: el aumento de casos de COVID-19 trajo la necesidad de reorganizar los servicios de salud. Se siguieron los siguientes pasos: identificación de pacientes programados, lectura de desarrollos clínicos en historias clínicas electrónicas, valoración individual para definir si se mantendría o no la cita, contacto telefónico para informar de la baja. De las 555 consultas programadas para marzo y abril de 2020, se mantuvieron 316 (56,9\%). Consideraciones finales: la reorganización de la atención en el ambulatorio de mastología optimizó el tiempo de espera para las consultas y evitó aglomeraciones en el servicio, brindando seguridad a los pacientes atendidos.

Descriptores: Infecciones por Coronavirus; Neoplasias de la Mama; Grupo de Atención al Paciente; Atención Ambulatoria; Salud de la Mujer. 


\section{INTRODUCTION}

COVID-19 is a disease caused by the SARS-CoV-2 coronavirus (Severe Acute Respiratory Syndrome Coronavirus 2) and has brought a threat to public health worldwide. In need of immediate changes, adaptations tend to be the way out to avoid contamination that potentially does not distinguish race, color, gender ${ }^{(1)}$.

The global numbers of suspected and confirmed cases are increasing every day. Up to May 18, 2020, 4,618,821 cases of COVID-19 (93,324 new in relation to the previous day) and 311,847 deaths $(4,452$ new in relation to the previous day) were confirmed worldwide $)^{(2)}$. Brazilian statistics indicate that the high rate of transmissibility brings collapses in the public health system, making the country one of the four largest nations in the number of confirmed coronavirus infections worldwide, surpassing even Spain and Italy ${ }^{(3)}$.

As spread is from one person to another through respiratory droplets or contact, special care must be taken concerning respiratory etiquette, hand washing with soap and water, among other precautions. Therefore, the ideal is that the circulation of citizens on public roads is reduced to prevent the disease to spread ${ }^{(1)}$.

Thus, it was necessary for some states and municipalities of the Brazilian federation to impose stricter restrictions on the movement of people in public places even in those territories with high population density and precarious housing ${ }^{(4)}$.

After the World Health Organization (WHO) revealed the COVID-19 pandemic, several health treatment centers in Brazil have been adopting measures so that there are no agglomerations of patients on their premises, which would increase the chances of infection. Even with such a worrying setting, there is a need for some outpatient care to remain because time is an influencing factor in the success of treatment ${ }^{(5)}$.

Particularly in cancer patients who have weakened immunity due to the disease itself, due to the post-surgical recovery status, treatment with chemotherapy, immunosuppressants, immunotherapy, radiotherapy, care about infection by COVID-19 brings great concern to the health team. Therefore, adjustments to procedures, routines, protocols and adequacy of physical spaces are necessary for safe care for this risk group so that monitoring and treatment are not suspended. In some cases, consultations are carried out with the aid of telemedicine by telephone ${ }^{(6-7)}$.

Thus, restructuring the health units to serve the public is necessary based on the determination of safety measures adjusted to serve users free of risks to contagion ${ }^{(8)}$. Thus, the mastology outpatient clinic in this study needed to have its care schedules reorganized by the health team in a short time to serve users safely.

\section{OBJECTIVE}

To report the experience of a health team in restructuring service at a mastology outpatient clinic.

\section{METHOD}

This is an experience report study regarding the performance of a health team in restructuring service at a mastology outpatient clinic of a public university maternity hospital in Ceará State in March and April 2020. The site is part of the University Hospital Complex, reference in assisting women in the pregnancy-puerperal cycle, with gynecological and mastological changes, under the sphere of the Unified Health System (Sistema Único de Saúde) in need of outpatient care or even, when necessary, high complexity care. In addition to the outpatient sectors, it has clinical inpatient units and adult and neonatal intensive care units.

The mastology clinic has four rooms for medical, nursing and physiotherapy, as well as four boxes for physical examination and procedures such as removal of suture points and suction drains, dressings, core biopsy, fine needle aspiration, incisional biopsy, among other outpatient procedures. The health team is composed of eight breast cancer specialists, two nurses, six nursing technicians, a physiotherapist, working from Monday to Friday divided into morning (7 a.m. to 1 p.m.) and afternoon (1 p.m. to 7 p.m.) shifts, except in holidays.

Although women with breast cancer are treated, the hospital where this clinic is located has only surgical treatment, referring to partner services those users in need of other treatment modalities such as radiotherapy, hormone therapy and chemotherapy; however, at the end of this stage, they return to service.

In the first quarter of 2020, an average of 926 women were served per month. The arrival flow of users takes place through the Central Regulation of the state or municipality, as well as referenced by other outpatient clinics in the Hospital Complex, or even by the emergency service. There are still those who have completed their treatments and are under follow-up.

With the state decree on social isolation on March 19, 2020, the design for restructuring services began; however, it was only on the following day that the steps were taken to reorganize service at the mastology outpatient clinic and start telephone calls to cancel appointments.

As the number of outpatient users is high, which normally causes crowds in the corridors, the first initiative was to avoid such a situation. But, for this, some steps were taken in order to guarantee the safety of them and the professionals. To this end, the interdisciplinary health team developed an integrated, interdependent, cohesive work, especially in short time.

The first stage included making a form with patient identification (full name, medical record number, telephone), date of the scheduled appointment and assistant breast cancer specialist. Subsequently, a nurse and a breast cancer specialist searched the electronic medical records through the University Hospitals Management Application (AGHU - Aplicativo de Gestão dos Hospitais Universitários) for consultations scheduled week by week starting on March 23, 2020.

Thereafter, the amount of daily care was limited, usually 6 patients/breast cancer specialist/shift. Thus, all the clinical progression of those patients scheduled for the following week were read and the need for early return to service was individually assessed. After signaling on the form those users whose consultations could be postponed, a telephone contact was made to inform about the temporary suspension.

The criteria used to maintain consultations were determined in accordance with the provisions of several medical societies, including the Medical Society of Oncological Surgery and outpatient team breast cancer specialists, whose idea was to stratify patients due to urgent treatment. Thus, consultations were classified as moderate or high benefit: returns for scheduling cancer surgery (mastectomy, quadrantectomy) in non-viable cases of hormone 
therapy use as a strategy for safe postponement of the procedure, postoperatively (removal of drains and suture points or monitoring of complications such as dehiscence and bruising), investigation of previously altered exams that indicated possible breast cancer, post-chemotherapy or post-radiotherapy to schedule the next steps. Delay in starting cancer treatments may mean a higher risk of failure and higher cancer mortality, even higher than the risk associated with a possible COVID-19 infections ${ }^{(6-7)}$.

\section{RESULTS}

Among the 555 consultations scheduled between March 20 to April 30, 316 (56.9\%) met the criteria previously established and were promptly attended by the health team. A significant number of patients were seen in a pandemic moment, although marked by rigorous individual assessment for their selection. However, for the remaining 239, whose consultations were flagged on the form that could be postponed, a telephone contact was made to inform about the temporary suspension, in addition to advising them on the subsequent rescheduling of consultations by telephone, depending on the direction of the health authorities to release outpatient care. It is noteworthy that with a lower demand from users, the waiting time remained reduced, since the number of professionals who performed the services remained.

It is important to highlight that, since the pandemic establishment of COVID-19 by WHO, the entry of any patient in the outpatient clinic was monitored by a properly trained nurse. This nurse was specially designated for this assignment through individual screening performed at the entrance before accessing the service facilities. At that time, patients were asked about flu-like symptoms and/or contact with people with the flu. If so, the team in the sector where the patient would be served was called to attend in a room prepared for such a situation, so the team responsible for the shift was attired according to the Brazilian Health Regulatory Agency (Agência Nacional de Vigilância Sanitária) recommendations.

This hospital protocol instituted for exclusively one-to-one screening at outpatient clinics was designed after meetings with nurses and physicians shortly after the onset of the disease in the city. Recognizing symptomatic patients, i.e., with respiratory symptoms even before entering health care facilities, constituted an essential routine for reducing patient and professional exposure, in addition to preventing disease progression ${ }^{(9)}$.

\section{DISCUSSION}

Initially, it is reinforced that public health worldwide has a great challenge ahead, since the disease caused by the new coronavirus does not yet have specific antiviral treatment or effective vaccine, although with promising research to achieve this goal ${ }^{(2)}$.
The reported experience supports some national health entities when proposing certain activities to control contamination by SARS-CoV-2, such as postponing consultations until the end of the pandemic period as well as follow-up exams, aiming to avoid unnecessary visits to the health service and, above all, agglomerations of users ${ }^{(5)}$.

Still in this context, the Pan American Health Organization/WHO recommends reducing exposure through social isolation, even in cases where there are mild symptoms suspected of infection ${ }^{(2,10)}$. However, health units are responsible for effective communication with patients, encouraging non-interruption of cancer treatment adjusted according to the local reality, considering risks and demands in addition to guidance on functioning during the pandemic period ${ }^{(9)}$.

Due to the limited number of studies, recommendations for patients with breast cancer are preliminary, and management is based on clinical experience and discussion by specialists and a multidisciplinary team. Therefore, some suggestions were made for prioritizing, treating and screening patients whose condition reflected an immediate threat to the continuation of life, where the prognosis would be significantly altered by the delay in service ${ }^{(11)}$.

The importance of the interdisciplinary health team's work stands out essentially when the main focus of their decisions is primarily based on patients. Considering that the primary purpose during this pandemic is to prioritize health risk reduction, in addition to providing satisfactory outcomes for patients with cancer, discussions are necessary to provide information, share decisions and discuss the benefits of starting, maintaining or suspending treatment during the pandemic period.

\section{Study limitations}

Lack of time to follow-up service after the restructuring to identify the results was a limitation of this study.

\section{Contributions to nursing, health, and public policy}

The role of nurses in the interdisciplinary team enables exchange, cooperation, planning, execution and assessment of care plan both under the administrative and assistance spheres.

\section{FINAL CONSIDERATIONS}

The report showed that restructuring patient service at a mastology outpatient clinic optimized the waiting time for these consultations and avoided crowds at service, providing patient safety and greater protection of their immunity.

The integration of the work of the interdisciplinary team was fundamental, since each professional intervened according to their knowledge and the technical or special differences were allied for decision-making in order to prevent, promote and rehabilitate the health of patients with breast cancer.

\section{REFERENCES}

1. Rothan HA, Byrareddy SN. The epidemiology and pathogenesis of coronavirus disease (COVID-19) outbreak. J Autoimmun. 2020;109:102433. doi: 10.1016/j.jaut.2020.102433 
2. Organização Pan-Americana da Saúde. Folha informativa - COVID-19 (doença causada pelo novo coronavírus) [Internet]. 2020 [cited 2020 Apr 13]. Available from: https://www.paho.org/bra/index.php?option=com_content\&view=article\&id=6101:covid19\&/temid=875

3. The NAM News Network (NNN). Coronavirus: Brazil overtakes Spain and Italy as new cases grow [Internet]. 2020 [cited 2020 Apr 13]. Available from: http://www.namnewsnetwork.org/?p=74959

4. Macedo YM, Ornellas JL, Bomfim HF. COVID-19 nas favelas e periferias brasileiras. Bol Conjuntura (BOCA). 2020;2(4):50-7. doi: 10.5281/ zenodo. 3748842

5. A.C. Camargo Cancer Center. Conheça os cuidados que essas pessoas devem manter para garantir a proteção contra o vírus [Internet]. 2020 [cited 2020 Apr 25]. Available from: https://www.accamargo.org.br/noticias/ covid-19-e-imunoterapia-em-pacientes-com-cancer-em-tratamento

6. Federação das Santas Casas de Misericórdia e Hospitais Beneficentes do Estado do Paraná (Femipa). Dramas e dilemas de pacientes com câncer em meio à pandemia COVID-19 [Internet]. 2020 [cited 2020 May 26]. Available from: http://www.femipa.org.br/noticias/ dramas-e-dilemas-de-pacientes-com-cancer-em-meio-a-pandemia-covid-19

7. Burki TK. Cancer guidelines during the COVID-19 pandemic. Lancet Oncol. 2020;21(5):629-30. doi: 10.1016/S1470-2045(20)30217-5

8. Secretaria de Saúde do Ceará. Nota técnica no 1. Retomada dos atendimentos ambulatoriais[Internet]. 2020 [cited 2020 Apr 25]. Available from: https://coronavirus.ceara.gov.br/wp-content/uploads/2020/06/03.06_Nota-Tecnica-Ambulatorial_V1.pdf

9. Ueda M, Martins R, Hendrie PC, McDonnell T, Crews, Jennie R, et al. Managing cancer care during the COVID-19 pandemic: agility and collaboration toward a common goal. J Natl Compr Canc Netw. 2020;1-4. doi: 10.6004/jnccn.2020.7560

10. Ramos RS. A Enfermagem Oncológica no enfrentamento da pandemia de Covid-19: reflexões e recomendações para a prática de cuidado em oncologia. Rev Bras Cancerol [Internet]. 2020 [cited 2020 Apr 25];66:e-1007. Available from: https://rbc.inca.gov.br/revista/index.php/ revista/article/view/1007/618

11. Dietz JR, Moran MS, Isakoff SJ, Kurtzman SH, Willey SC, Burstein $\mathrm{HJ}$, et al. Recommendations for prioritization, treatment, and triage of breast cancer patients during the COVID-19 pandemic. The COVID-19 pandemic breast cancer consortium. Breast Cancer Res Treat. 2020;181(3):487-97. doi: 10.1007/s10549-020-05644-z 